\title{
Molecular Characterization of Group A Rotavirus Isolates Obtained from Hospitalized Children in Salvador, Bahia, Brazil
}

\author{
Karina Serravalle ${ }^{1}$, Norma Santos ${ }^{2}$, Silvia Inês Sardi ${ }^{1}$, Sarah Peregrino Santos Silva ${ }^{1}$, Hugo da Costa Ribeiro Junior ${ }^{3}$, \\ Ângela Peixoto de Mattos $^{3}$ and Gúbio Soares Campos ${ }^{1}$ \\ ${ }^{1}$ Laboratory of Virology, Institute of Science Health, Federal University of Bahia, Salvador, BA; ${ }^{2}$ Laboratory of Virology, Federal University of \\ Rio de Janeiro, RJ; ${ }^{3}$ Metabolic Department Fima Lifshtz, Hosannah de Oliveira Pediatric Hospital; Salvador, BA, Brazil
}

\begin{abstract}
Rotavirus is a major cause of infectious diarrhea in infants and young children. The objective of this study was to characterize the genotypes of Human Rotavirus found in children hospitalized with acute diarrhea in the Pediatric Hospital Prof. Hosannah de Oliveira of the UFBA in Salvador, Bahia, Brazil, during the years of 1999, 2000 and 2002. Fecal samples were analyzed $(n=358)$ by methods EIARA and SDS-PAGE for detection of Rotavirus. Positive samples of one or two of these methods (n=168) were submitted to RT-PCR and Multiplex-Nested PCR to determine genotypes G and P. A hundred sixty-eight $(46.9 \%)$ samples were positive and $190(53.1 \%)$ negative. Only 17 (4.7\%) samples had divergent results. The distribution of genotypes G during the first year, showed that the genotype G9 was present in $96,8 \%$ of the analyzed samples, in the second year, it was responsible for $96 \%$ and in the third year, $88,1 \%$. The characterization of genotypes $P$ demonstrated that the genotype P1A[8] was the most outstanding in all years. In this study we discuss the benefit to control the genotypes of Rotavirus through the molecular characterization for the development of potential vaccines.

Key-Words: Rotavirus, PCR, genotype, children.
\end{abstract}

Rotavirus is the most common cause of gastroenteritis in children under five years of age. Between 400,000 and 600,000 children are estimated to die annually worldwide as a result of this infection [1-3].

In Brazil, the first registered case of rotavirus occurred in 1976, in the city of Belém, state of Pará [4], when the virus was detected by electronic microscopy in the feces of children with diarrhea. Since that time, it has been diagnosed in various Brazilian states, confirming the importance of this virus in the etiology of childhood diarrhea [5-7].

Rotavirus is an icosahedral virus measuring $70 \mathrm{~nm}$ in diameter with a double capsid and a viral genome composed of 11 segments of double-stranded RNA. Rotaviruses are classified in seven groups (A-G) based on the antigenic characteristics of the capsid proteins. Group A has a wide antigenic and genomic diversity, with various serotypes and genotypes, mainly due to variations in the VP4 and VP7 proteins of the external capsid. The types specified by the VP7 protein are denominated G serotypes/genotypes (glycoprotein) and those specified by the VP4 protein are denominated $\mathrm{P}$ serotypes/genotypes (sensitive to proteolysis) [8].

To this date, $14 \mathrm{G}$ serotypes/genotypes (G1-G14), of which G1, G6, G8, G10 and G12 infect humans, and 21 P genotypes (P1P21), of which P1A[8], P1B[4], P2A[6], P3[9], P3B[13], P4[10], $\mathrm{P5}[3]$ and P8[11] infect humans [8,3,9], have been described.

Received on 12 July 2006; revised 19 December 2006.

Address for correspondence: Dr. Gúbio Soares Campos. Laboratório de Virologia. Instituto de Ciências da Saúde, Universidade Federal da Bahia Av. Reitor Miguel Calmon s/n, Vale do Canela. Zip code: 40110-100. Salvador, Bahia, Brazil. E-mail: gubio@ufba.br. Telephone/Fax: (5571) 3235-0937.

Support:Fundação de Amparo à Pesquisa do Estado da Bahia (FAPESB).

The Brazilian Journal of Infectious Diseases 2007;11(1):35-39. (C) 2007 by The Brazilian Journal of Infectious Diseases and Contexto Publishing. All rights reserved.
Based on a binary classification system of the combination of $\mathrm{P}$ and $\mathrm{G}$, the majority of genotypes isolated in children with diarrhea caused by rotavirus infection are P1A[8]G1, P1B[4]G2, P1A[8]G3 and P1A[8]G4 [10,11,7]. Recent studies show that the incidence of P1A[8]G9 and P2A[6]G9 genotypes as a cause of severe diarrhea in children all over the world, including Brazil, has been increasing. For this reason, studies on the molecular epidemiology of this virus are important in order to determine the genotypes circulating within a community and to enable the possible implementation of vaccines [12-24].

The objective of this study was, therefore, to characterize the genotypes of Human Rotavirus detected over a period of three years in children admitted to a pediatric hospital with acute diarrhea caused by this virus. Data resulting from this study would contribute towards epidemiological investigation by characterizing the rotavirus genotypes detected in hospitalized children, reflecting the presence of the virus in the community.

\section{Materials and Methods}

Samples for Rotavirus Testing

During the years of 1999, 2000 and 2002, fecal samples were collected from children under five years old $(n=358)$ with acute diarrhea, in the Fima Lifshtz Metabolic Unit of the Hosannah Oliveira Pediatric Hospital in Salvador, Bahia, Brazil. The feces were collected in sterile containers and kept frozen at $-20^{\circ} \mathrm{C}$ until analysis.

\section{Rotavirus Detection}

Two different detection methods were used to verify the presence of the virus in the fecal samples $(n=358)$.

Enzyme Immunoassay (EIARA - Combined Enzyme Immunoassay for Rotavirus and Adenovirus). The presence of the virus in the fecal samples was detected using a double- 
sandwich, enzyme-linked immunosorbent assay (ELISA), (Fundação Oswaldo Cruz, Ministry of Health, Brazil), according to the instructions provided by the manufacturer [25].

Polyacrylamide Gel Electrophoresis (SDS-PAGE): Electropherotypes. The fecal samples were submitted to RNA extraction using Trizol LS reagent (Life Technologies Inc., Grand Island, NY) followed by precipitation in ethanol. The precipitated viral RNA was re-suspended in denaturing Laemmli buffer [26] and submitted to vertical electrophoresis in SDS-PAGE 7.5\%. The presence of viral RNA in the fecal sample was confirmed following staining with a $7 \mathrm{mM}$ silver nitrate solution [27].

\section{Cell Culture: Viral Isolation}

MA-104 cell culture maintained in Eagle's minimum essential medium (GIBCO-BRL), supplemented with $10 \%$ fetal bovine serum (GIBCO-BRL) and antibiotic-antimycotic solution (GIBCO-BRL) was used in this study. When direct genotyping was unsuccessful, positive fecal samples $(n=60)$ were centrifuged at $10,000 \mathrm{~g}$ and the supernatant used to inoculate the MA-104 cell monolayers, carrying out up to three consecutive passages following 72 hours of culture. The infected cell cultures were then used for the extraction of RNA as described later.

Multiplex RT-PCR Assays: G and P Genotyping

The samples that were classified as positive by ELISA or SDS-PAGE ( $\mathrm{n}=168$ ) were used to determine $\mathrm{G}$ and Pgenotypes. These samples were submitted to the Polymerase Chain Reaction (PCR) technique with reverse transcriptase (RT) for the genes that codify VP4 and VP7, and later to a MultiplexNested PCR combining specific primers to amplify the G1-G10 or the P1-P4 genotypes [28].

In summary, a $10 \mu \mathrm{L}$ aliquot of the viral RNA extracted using the Trizol method (Life Technologies Inc., Grand Island, $N Y$ ) from the fecal samples $(\mathrm{n}=108)$ or from the infected cell culture $(\mathrm{n}=60)$, was denatured at $97^{\circ} \mathrm{C}$ for 5 minutes and then added to a tube containing the Beg9 and End9 primers $(1 \mu \mathrm{M})$ for VP7 or Con3 and Con2 $(1 \mu \mathrm{M})$ for VP4, with a Master Mix solution, containing Taq DNA polymerase (0.5 U), dATP, dGTP, dCTP, dTTP $(200 \mu \mathrm{M})$ and $\mathrm{MgCl}_{2}(1.5 \mathrm{mM})$ (Promega Corporation, Madison, USA) and 5 units of the reverse transcriptase enzyme (Promega Corporation, Madison, USA), with a final reaction volume of $50 \mu \mathrm{L}$. This final mixture was submitted to 30 cycles at $94^{\circ} \mathrm{C}$ for 2 minutes, $55^{\circ} \mathrm{C}$ for 1 minute and $72^{\circ} \mathrm{C}$ for 5 minutes, followed by a final extension cycle of $72^{\circ} \mathrm{C}$ for 5 minutes (GeneAmp PCR System 2400, Perkin Elmer). This first RT-PCR was the basis of the subsequent genotyping (Multiplex-nested PCR) and determination of the G genotype. The product of RT-PCR ( $5 \mu \mathrm{L})$ was added to a solution containing each one of the primer sets, H2, A, C [29] $(1 \mu \mathrm{M})$, together with the Master Mix solution (composed of Taq DNA Polymerase (5U), dATP, dGTP, dCTP, dTTP (200 $\mu \mathrm{M})$ and $\mathrm{MgCl}_{2}$
(1.5mM), (Promega Corporation, Madison, USA) to a final volume of $50 \mu \mathrm{L}$. The reaction was submitted to 15 cycles at $94^{\circ} \mathrm{C}$ for one minute, $55^{\circ} \mathrm{C}$ for 2 minutes, $72^{\circ} \mathrm{C}$ for 1 minute, followed by $72^{\circ} \mathrm{C}$ for 7 minutes (extension), (GeneAmp PCR System 2400, Perkin Elmer). To determine the P genotype, the procedure was the same, using the $P$ primer set $[28,29](1 \mu \mathrm{M})$ submitted to 25 cycles at $94^{\circ} \mathrm{C}$ for one minute, $55^{\circ} \mathrm{C}$ for 2 minutes, $72^{\circ} \mathrm{C}$ for 3 minutes, followed by $72^{\circ} \mathrm{C}$ for 7 minutes.

The PCR products were submitted to an agarose gel electrophoresis, placed in an ethidium bromide solution $(1 \mu \mathrm{g} /$ $\mathrm{mL}$ ) (Sigma Chemical Company) for 10 minutes and photographed using a Polaroid film in an ultraviolet light transilluminator.

\section{Statistical Analysis}

Analysis of the results was carried out using the statistical software programs SPSS version 9.0, and Epi-Info, version 6.04 .

\section{Results}

Detection of Rotavirus by ELISA/SDS-PAGE (Electropherotypes)

Table 1 compares the results of the ELISA and SDS-PAGE techniques. During the years of 1999, 2000 and 2002, the analysis of the 358 samples using the ELISA (EIARA) and SDS-PAGE techniques resulted in 168 positive samples (46.9\%) and 190 negative samples (53.1\%). Agreement between the results obtained by these two methods was $95.3 \%$, only 17 samples having discordant results: 13 were positive according to EIARA but negative according to the SDS-PAGE technique, while 4 were positive according to the SDS-PAGE technique but negative according to EIARA.

Figure 1 shows the electrophoretic profile of the rotaviruspositive samples, showing that the migration of the 11 segments of RNA followed a 4:2:3:2 pattern that is characteristic of the group A rotavirus. Interestingly, due to duplication of one viral segment, one sample had 12 RNA segments suggesting a possible genetic recombination.

Genetic Analysis of the VP4 and VP7 Genes: RT-PCR Genotyping

The results obtained by RT-PCR are shown in Figure 2. The presence of the 1062-bp consensus fragment corresponds to the amplification of the gene that codifies for VP7 and the 876-bp consensus fragment corresponds to the gene that codifies for the VP4 protein. Of the samples that were positive according to at least one of the methods used (ELISA or SDSPAGE), ( $\mathrm{n}=168$ ), it was possible to amplify VP7 and VP4 using the RT-PCR technique in 163 samples (97.0\%).

The result of Multiplex-nested PCR genotyping for the G (VP7) and P (VP4) genotypes is shown in Tables 2 and 3. Table 2 shows the distribution of $G$ genotypes. In a total of 157 samples, 96.8\% (30/31) belonged to the G9 genotype group during the first year of the study, while the G1 genotype was present in only one sample (3.2\%). In the second year, G9 was 
Table 1. Detection of Rotavirus by ELISA and SDS-PAGE in the feces of children hospitalized in the city of Salvador, Bahia, Brazil, 1999, 2000 and 2002

\begin{tabular}{lccl}
\hline \multirow{2}{*}{ ELISA• } & \multicolumn{2}{c}{ SDS - PAGE* } & \multirow{2}{*}{ Total } \\
\cline { 2 - 3 } & Negative & Positive & \\
\hline Negative & $190(53.1 \%)$ & $4(1.1 \%)$ & $194(54.2 \%)$ \\
Positive & $13(3.6 \%)$ & $151(42.2 \%)$ & $164(45.8 \%)$ \\
Total & $203(56.7 \%)$ & $155(43.3 \%)$ & $358(100.0 \%)$ \\
\hline
\end{tabular}

•Enzyme immunoassay (EIARA - Combined Enzyme Immunoassay for Rotavirus and Adenovirus).

*Polyacrylamide gel electrophoresis (SDS-PAGE).

Figure 1. 7.5\% Polyacrylamide gel electrophoresis, (SDSPAGE), of RNA from Human Rotavirus, extracted from fecal specimens from children during the years of 1999, 2000 and 2002 in Salvador, Bahia Brazil. Column 1: SA-11; 2-13 virus, fecal samples positive for Rotavirus; 14, RNA of Bovine Rotavirus; 15, negative fecal sample. Column 11: Fecal sample with 12 segments of RNA. All samples presented an electrophoretic profile of 4:2:3:2, characteristic of viral RNA of the group A Rotavirus.

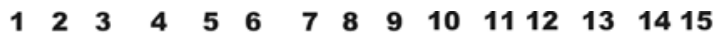

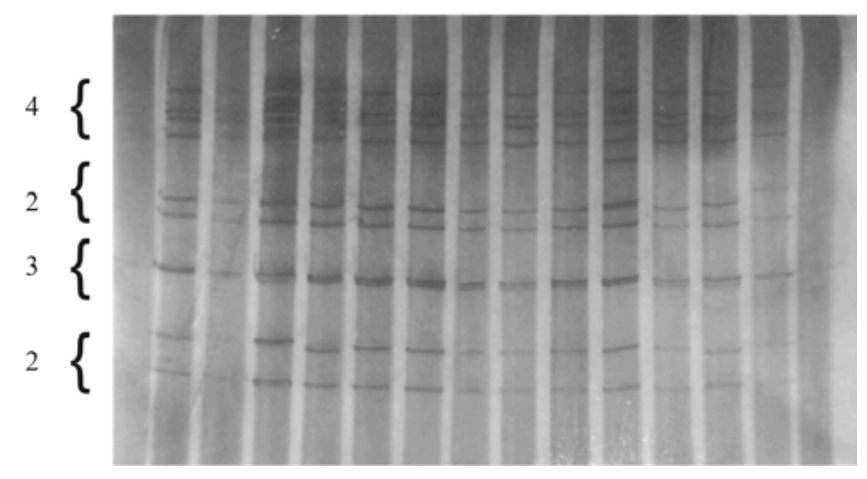

present in $96.0 \%(24 / 25)$ of the samples analyzed and genotype G4 in 4.0\% (1/25). In the third year, G9 was found in 88.1\% (89/ 101 ) of the samples, genotype G1 in $10.9 \%$ (11 samples), and genotype G4 in 1\% (1 sample). Although not statistically significant ( $p=0.097$ ), the incidence of the $G 9$ genotype would appear to be declining over the years.

Table 3 shows that the $\mathrm{P}$ genotypes were found in 144 (85.7\%) samples. Analysis of the distribution frequency of the genotypes in the two first years shows that the P1A[8] genotype was present in $100 \%$ of samples. In the studies carried out in the third year, this same genotype was present in $98.9 \%(89 / 90)$ of samples, while genotype P1B[4] was present in only $1.1 \%$ (1/90) of samples.

Figure 3 shows the amplified products of the P1A[8], G1 and G9 genotypes.

\section{Discussion}

Studies carried out in Brazil in different geographical regions of the country indicate that the frequency of diarrhea associated with rotavirus in children under the age of 5 admitted to hospital or receiving care in clinics ranges from $12 \%-42 \%[29,30]$, similar to those found in our study in which the presence of rotavirus was confirmed in $46.9 \%$ of the samples analyzed. The genetic characteristics of the virus provide characterization of the molecular aspects of the infection, thereby providing new data on the evaluation of the predominant genotypes of the isolated virus. In this study, rotavirus genotyping, using RT-PCR and Multiplex-nested PCR revealed the presence of genotypes $G$ and $P$ of the virus present in the feces of infected children. Of the G genotypes in this study, genotype G9 was identified as being predominant (85.2\%), followed by G1 and G4. Other recent studies in Brazil have also shown emergence of genotype G9 [31,32]. The G9 genotype was considered an uncommon genotype, reported for the first time in 1983/1984 in a pediatric hospital in Philadelphia, USA, with a frequency of only $9.2 \%$, whereas later studies (1995-1996) showed a much higher incidence (56\%) [33]. Following this finding, several countries were alerted to the presence of G9 and current percentages range

Table 2. Distribution of the G genotypes of Human Rotavirus detected in the fecal samples of children hospitalized in the city of Salvador, Bahia, Brazil, 1999, 2000 and 2002

\begin{tabular}{|c|c|c|c|c|c|c|}
\hline Year & $\begin{array}{c}\text { Viral } \\
\text { detection }\end{array}$ & G1 & $\begin{array}{c}\text { Genotypes } \\
\text { G4 }\end{array}$ & G9 & $\begin{array}{l}\text { Samples } \\
\text { that did not undergo } \\
\text { genotyping }\end{array}$ & Total \\
\hline 1999 & 31 & $1(3.2)^{*}$ & - & $30 * * \quad(96.8)$ & 2 (6.1) & 33 \\
\hline 2000 & 25 & - & $1(4.0)$ & $24(96.0)$ & $1(3.8)$ & 26 \\
\hline 2002 & 101 & 11(10.9) & $1(1.0)$ & 89 (88.1) & $8(7.3)$ & 109 \\
\hline Total & $157(93.5)$ & $12(7.1)$ & $2(1.2)$ & $143(85.2)$ & $11(6.5)$ & 168 \\
\hline
\end{tabular}

*Numbers in parentheses, percent.

**The incidence pattern of G1 and G9 was similar during 1999, 2000 and 2002 ( $p=0.29)$. 
Figure 2. Products of amplification of the VP7 and VP4 Rotavirus genes by RT-PCR. Line 1: 876-bp consensus fragment for VP4; 2 - 1062-bp consensus fragment for VP7; 3Negative control; $\mathrm{M}$ - Marker of molecular weight of $50 \mathrm{bp}$ (Promega). DNA molecular marker 50 bp.

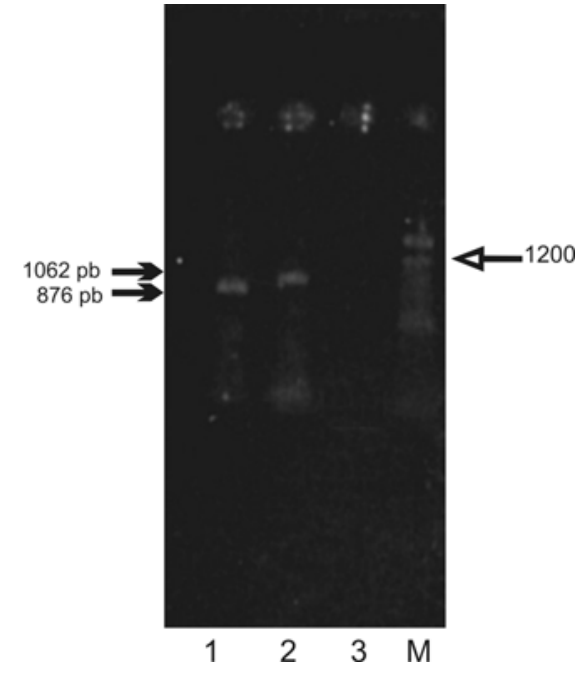

Figure 3. Electrophoretic profile of the amplification products of the genes (VP7/VP4) of Rotavirus by Multiplex-Nested RTPCR in fecal samples from children hospitalized during the years of 1999, 2000 and 2002 in Salvador, Bahia, Brazil. Lines 1-2: Genotype G3 (582 bp); 3: Genotype G1 (749 bp); 4: Genotype P1A[8] (345 bp); 5: Genotype G9 (306 bp); 6: Negative control; M: Marker of molecular weight of 50 bp. DNA molecular marker 50 bp.

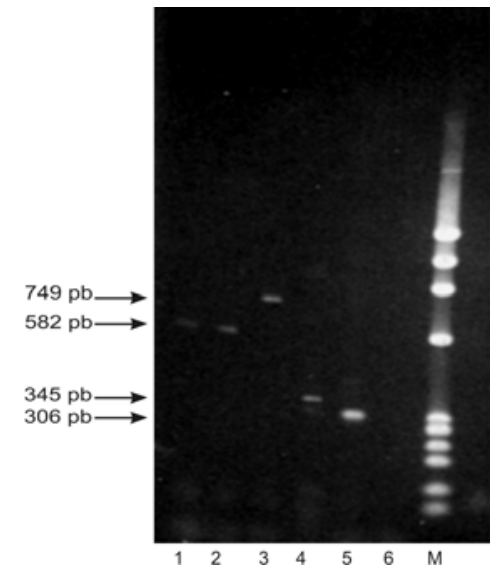

Table 3. Distribution of the frequency of the P genotypes of Human Rotavirus in fecal samples of children hospitalized in the city of Salvador, Bahia, Brazil, 1999, 2000 and 2002

\begin{tabular}{lccccc}
\hline Year & Viral detection & P1A[8] & P1B[4] & $\begin{array}{c}\text { Samples that did not } \\
\text { undergo genotyping }\end{array}$ & Total \\
\hline 1999 & 30 & $30(100.0)^{*}$ & - & $3(9.1)$ & 33 \\
2000 & 24 & $24(100.0)$ & - & $2(7.7)$ & 26 \\
2002 & 90 & $89(98.9)$ & $1(1.1)$ & $19(17.4)$ & 109 \\
Total & $144(85.7)$ & $143(85.1)$ & $1(0.6)$ & $24(14.3)$ & 168 \\
\hline
\end{tabular}

*Numbers in parentheses, percent.

from $0.4 \%$ to $78.4 \%[14,34,35,23,15]$. The existence of these uncommon genotypes raises the question of whether they really represent emerging infections or if they were simply not diagnosed appropriately until now [34,36,37,16,38,18,39,23,24].

With respect to the characterization of $P$ genotypes, the $\mathrm{P} 1 \mathrm{~A}[8]$ and $\mathrm{P} 1 \mathrm{~B}[4]$ genotypes were the most relevant, and these data are in agreement with results from other studies in which the predominant genotypes found in humans were $\mathrm{P} 1 \mathrm{~A}[8]$ and $\mathrm{P} 1 \mathrm{~B}[4]$ followed by P2A[6] [40,32].

In our study, it was not possible to characterize the genotypes in some samples. The presence of enzyme inhibitors or variations in the succession of nucleotides in the hybridization area of the primers may be responsible for inadequate amplification. Today, the majority of studies on the molecular characterization of rotavirus use, as in our case, more than one group of primers able to identify genotypes of human or animal origin, such as G9 of bovine origin [31]. Nevertheless, the lack of characterization of some samples may suggest the presence of new genotypes.

The results of this study show the molecular characterization of the rotavirus over a period of three years in hospitalized children with acute diarrhea, emphasizing the presence of the P1A[8] and G9 genotypes as being predominant in this area. The occurrence of uncommon $\mathrm{P}$ and/ or $\mathrm{G}$ genotypes, reinforces the need for constant surveillance of the molecular epidemiology of rotavirus with a view to developing a possible vaccine, and to initiate new discussions with respect to whether the clinical manifestations may be associated with certain genotypes.

\section{Acknowledgments}

The authors thank the financial support of FAPESB and to the support received by the personnel of the Unidade Metabólica Fima Lifshtz, Hospital Pediátrico Hosannah de Oliveira. The authors would like to thank Dr. Eduardo Martins Neto for carrying out the statistical analysis.

\section{References}

1. Glass R.I., Bresee J.S., Parashar U.D., et al. The future of rotavirus vaccines: a major setback leads to new opportunities. The Lancet 2004;363:1547-50.

2. Midthun K., Kapikian A.Z. Rotavirus vaccines: an overview. Clin Microbiol Rev 1996;9:423-34. 
3. Kapikian A.Z., Hoshino Y., Chanock R.M. Rotaviruses. In: Fields B.N., Knipe D.M., Howley P.M., et al. Virology. 4th ed. Philadelphia: Lippincott-Raven Press, 2001:1787-1833 cap. 55.

4- Linhares A.C., Pinheiro F.P., Schmetz C., et al. Rotavírus em Belém do Pará, Brasil (estudo-piloto). Rev Inst Med Trop São Paulo 1977;24:292-7.

5. Pereira H.G., Linhares A.C., Candeias J.A.N., Glass R.I. Vigilancia de los virus de la gastroenteritis en los laboratorios nacionales del Brasil. Bol Ofic Sanit Panam 1994; 116:27-36.

6. Leite J.P.G., Alfieri A.A., Woods P.A., et al. Rotavirus G and P types circulating in brazil: characterization by RT-PCR, probe hybridization, and sequence analysis. Arch Virol 1996;141:2365-74.

7. Santos N., Gouvea V. Infecções por rotavírus: aspectos atuais. J Bras Patol 1997;33:94-102.

8. Estes M.K. Rotaviruses and their replication. In: Fields B.N., Knipe D.M., Howley P.M., et al. Virology. Filadelfia: Lippincott-Raven, 2001:1747-1785, cap. 54.

9. Parashar U.D., Bresee J.S., Gentsch J.R., Glass R.I. Rotavirus. Em Infect Dis 1998;4:561-7.

10. Coulson B.S., Gentsch J.R., Bimal K.D., et al. Comparison of enzyme immunoassay and reverse transcriptase PCR for identification of serotype G9 rotaviruses. J Clin Microb 1999;37:3187-93.

11. Santos N.S.O. Viroses entéricas. In: Santos N.S.O. Romanos M.T.V., Wigg M.D. Introdução à Virologia Humana. Rio de Janeiro: Guanabara Koogan, 2002:59-63. cap.6.

12. Adah M.I., Wade A.,Taniguchi K. Molecular epidemiology of rotaviruses in Nigeria: detection of unusual strains with G2P[6] and G8P[1] specifities. J Clin Microbiol 2001;39:3969-75.

13. Araujo I.T., Ferreira M.S.R., Fialho, et al. Rotavirus genotypes P[4]G9, P[6]G9, and P[8]G9 in hospitalized children with acute gastroenteritis in Rio de Janeiro, Brazil. J Clin Microbiol 2001;39:1999-2001.

14. Araujo I.T., Fialho A.M., Assis R.M.S., et al. Rotavirus strain diversity in Rio de Janeiro, Brazil: characterization of VP4 and VP7 genotypes in hospitalized children. J Trop Ped 2002;48:214-8.

15. Armah G.E., Steele A.D., Binka F.N., et al. Changing patterns of rotavirus genotypes in Ghana: emergence of human rotavirus G9 as a major cause of diarrhrea in children. J Clin Microbiol 2003;41:2317-22.

16. Kirkwood C., Bogdanovic-Sakran N., Palombo E., et al. Genetic and antigenic characterization of rotavirus serotype G9 isolated in Australia between 1997 and 2001. J Clin Microbiol 2003;41:3649-54.

17. Laird A.R., Gentsch J.R., Nakagomi T., et al. Characterization of serotype G9 rotavirus strains isolated in the United States and India from 1993 to 2001. J Clin Microbiol 2003;41:3100-11.

18. Martella V., Terio V., Gaudio G.D., et al. Detection of the emerging rotavirus G9 serotype at high frequency in Italy. J Clin Microbiol 2003;41:3960-3.

19. Ramachandran M., Kirkwood C.D., Unicomb L., et al. Molecular characterization of serotype G9 rotavirus strains from a global collection. Virology 2000;278:436-44.

20. Santos N., Volatão E.M., Soares C.C., et al. Rotavirus strains bearing genotype G9 or P[9] recovered from brazilian children with diarrhea from 1997 to 1999. J Clin Microb 2001;39:1157-60.

21. Silva M.L.R., Carvalho I.P., Gouvea V. 1998-1999. Rotavirus seasons in Juiz de Fora, Minas Gerais, Brazil: detection of an unusual G3P[4] epidemic strain. J Clin Microbiol 2002;40:2837-42.
22. Steele A.D., Ivanoff B., African Rotavirus Network. Rotavirus strains circulating in Africa during 1996-1999: emergence of G9 strains and P[6] strains. Vaccine 2003;21:361-7.

23. Villena C., El-Senousy W.M., Abad F.X., et al. Group A rotavirus in sewage samples from Barcelona and Cairo: emergence of unusual genotypes. Appl Env Microbiol 2003;69:3919-23.

24. Zhou Y., Li L., Okitsu S., et al. Distribution of human rotaviruses, especially G9 strains, in Japan from 1996 to 2000. Microbiol Immunol 2003;47:591-9.

25. Pereira H.G., Azeredo R.S., Leite J.P.G., et al. A combined enzyme immunoassay for rotavirus and adenovirus. J Virol Meth 1985; $10: 21-8$

26. Laemmli U.K. Cleavage of structural proteins during the assembly of the head of bacteriophage T4. Nature 1970;227:680-5.

27. Herring A.J., Inglis N.F., Ojeh C.K., et al. Rapid diagnosis of rotavirus infection by direct detection of viral nucleic acid in silver-stained polyacrylamide gels. J Clin Microbiol 1982; $16: 473-7$

28. Gouvea V., Glass R.I., Woods P., et al. Polymerase chain reaction amplification and typing of rotavirus nucleic acid from stool specimens. J Clin Microbiol 1990;28:276-82.

29. Linhares A.C. Epidemiologia das infecções por rotavirus no Brasil e os desafios para seu controle. Cad Saúde Publ 2000;16:1-29.

30. Cardoso D.D.P., Soares C.M.A., Souza M.B.L.D., et al. Epidemiological features of rotavírus infection in Goiânia, Goiás, Brazil, from 1986 to 2000. Mem Inst Oswaldo Cruz 2003;98:25-9.

31. Santos N., Volatão E.M., Soares C.C., et al. VP7 gene polymorphism of serotype G9 rotavirus strains and its impact on G genotype determination by PCR. Virus Res 2003;93:127-38.

32. Souza M.B.L.D., Rácz M.L., Leite J.P.G., et al. Molecular and serological characterization of group A rotavirus iIsolates obtained from hospitalized children in Goiânia, Brazil, 19982000. J Clin Microbiol Infect Dis 2003;22:441-3.

33. Clark H.F., Hoshino Y., Bell L.M., et al. Rotaviruses isolate W161 representing a presumptive new human serotype. J Clin Microbiol 1987;25:1757-62.

34. Bon F., Fromantin C., Aho S., et al. G and P genotyping of rotavirus strains circulating in France over a three-year period: detection of G9 and P[6] strains at low frequencies. J Clin Microbiol 2000;38:1681-3.

35. Ramachandran M., Gentsch J.R., Parashar U.D., et al. Detection and characterization of novels rotavirus strains in the United States. J Clin Microbiol 1998;36:3223-9.

36. Coluchi N., Munford V., Manzur J., et al. Detection, subgroup specificity, and genotype diversity of rotavirus strains in children with acute diarrhea in Paraguay. J Clin Microbiol 2002;40:170974.

37. Griffin D.D., Kirkwood C.D., Parashar U.D., et al. Surveillance of rotavirus strains in the United States: identification of unusual strains. J Clin Microbiol 2000;38:2784-7.

38. Kostouros E., Siu K., Ford-Jones E.L., et al. Molecular characterization of rotavirus strains from children in Toronto, Canada. J Clin Virol 2003;28:77-84.

39. Palombo E.A., Masendycz P.J., Bugg H.C., et al. Emergence of serotype G9 human rotaviruses in Australia. J Clin Microbiol 2000;38:1305-6.

40. Hoshino Y., Kapikian A.Z. Classification of rotavirus VP4 and VP7 serotypes. Arch Virol 1996;12:99-111. 